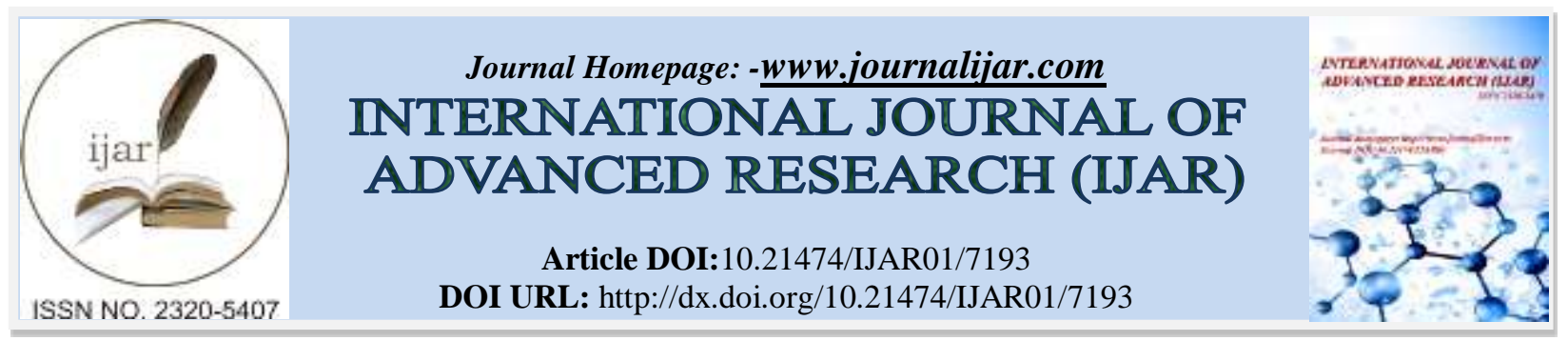

RESEARCH ARTICLE

\title{
AN EPIDEMIOLOGICAL ASSESSMENT OF CHILD INJURIES IN ZAGAZIG UNIVERSITY HOSPITALS; PATTERNS AND MANAGEMENT MODALITIES.
}

\author{
Omar Atef Elekiabi ${ }^{1}$, Walid A. Mawla ${ }^{1}$, Ibtsam Shehta Harera ${ }^{1}$, Tamer Mohamed El shahidy ${ }^{1}$, Mohamed Farouk Amin ${ }^{1}$ and Samar A. \\ Amer'. \\ 1. Department of General Surgery, Faculty of medicine, Zagazig University, Zagazig, Egypt. \\ 2. Public health and community medicine, Faculty of Medicine, Zagazig University.
}

\section{Manuscript Info}

\section{Manuscript History}

Received: 03 April 2018

Final Accepted: 05 May 2018

Published: June 2018

Keywords:-

Zagazig, child, injury, agent, host, environment, injury, mortality, disability, prevention.

\section{Abstract}

Background: Trauma is the leading cause of death in childhood. Among children aged from 1 to 14 years, approximately $50 \%$ of mortality is related to trauma.

Aim: to evaluate child injury in Zagazig University Hospitals in the light of agent-host-environment triangle.

Objectives: To study the types and pattern of child injury received in the hospital, to study the outcome of child injury (death, temporary disability or permanent disability) and to formulate suggested preventive measures according to Haddon's matrix.

Patient and methods: This observational cross sectional study was conducted in Zagazig University Hospitals and included children who suffered injuries during the period from April 2013 to April 2015. A pre-designed format was used to collect data in the light of Haddon matrix.

Results: School age children were the most commonly injured with the mean age of presentation 6.5 years. Boys to girls' ratio were 2.1: 1and abdominal injuries were the commonest. Mortality rate was $(4.47 \%)$. Mechanical energy was the most common energy. Road traffic accident was the commonest vector. Roads were the most common site for child injury and more common among children living in low socioeconomic states.

Conclusion: we conclude that majority of pediatric injuries are preventable and pediatric epidemiological trends differ from those in adults. Therefore, preventive strategies should be made in pediatric patients on the basis of these epidemiological trends.

Copy Right, IJAR, 2018,. All rights reserved.

\section{Introduction:-}

Trauma is the leading cause of death in childhood. Among children aged from 1 to 14 years. It results in disability and death more than other childhood diseases. More than 10,000 children die from trauma at USA each year. Approximately $10 \%$ of pediatric hospitalization, $15 \%$ of pediatric intensive care unit hospitalization, $25 \%$ pediatric emergency admission and $50 \%$ of pediatric ambulance need (cooper, 2014).In Egypt, the newly developed injury registry Program in the Ministry of health done in (2002). Injury surveys conducted in different parts of the country (Universities and MOHP). Registry program did not include all health facilities, and even 
University Hospitals. Poor recording system in most of the health facilities, even university hospitals (40\% unidentified cause of trauma) (Fathy H, 2005).

Pediatric trauma affects both sexes and all economic, racial, and social backgrounds in the United States. Children are injured in rural, suburban, and urban environments (Ehrlich et al., 2008).

The agent-host-environment model has been used to describe the epidemiology of communicable diseases. It can be adapted for understanding childhood injuries. The agent of injury is the form of energy that damages body tissues. The host or injured child can be described by age, sex, race, developmental level and behavior characteristics. Finally, the environment includes the physical situation, in which injuries occur as well as the psycho-social environment (Guyer and Gallagher, 1985).

William Haddon developed a scheme (known as the "Haddon Matrix") in the 1960s to apply the principles of public health to the problem of road traffic safety (Runyan, 1998). It has since been used as a means of developing ideas to prevent injury of all types. The matrix consists of 12 cells. These are arranged in a table of four columns relating to the host, agent/vehicle, physical environment and social environment, and of three rows relating to the periods before, during and after the injury. The resulting matrix provides a means to identify, cell by cell: strategies and priorities for injury prevention, in terms of their costs and effects; existing research and research that needs to be undertaken; the allocation of resources in the past and the future, and the effectiveness of such allocation. Haddon went on to describe 10 strategies to accompany the matrix, which describe the ways in which the harmful transfer of energy can be prevented or controlled in some way. The significance of the Haddon Matrix and Haddon's 10 injury prevention countermeasures is that they highlight the fact that not only can society intervene to reduce injury, but that such interventions can occur at different stages (Christoff and Gallagher 1999).

Aim:-

To evaluate child injury in Zagazig University Hospitals in the light of agent-host-environment triangle.

Objectives:-

To study the types and pattern of child injury received in the hospital, to study the outcome of child injury (death, temporary disability or permanent disability) and to formulate suggested preventive measures according to Haddon's matrix.

\section{Patients and Methods:-}

This observational cross sectional study was conducted in Zagazig University Hospitals and included children who suffered injuries during the period from April 2013 to April 2015.

\section{Inclusion criteria:-}

1. Age less than 14 years.

2. Admitted to The Surgical Emergency Unit in Zagazig University Hospitals.

\section{Exclusion criteria:-}

1. Age more than 14 year.

2. Patients admitted to non-surgical emergency units.

\section{Patient evaluation:-}

A pre-designed format was used to collect data in the light of Haddon matrix Fig (1), included either direct or indirect incidents.

The socioeconomic level was determined according to El- Sherbini and Fahmy scoring systems for socioeconomic status. Accordingly patients were classified into low, intermediate or high socio-economic level (Fahmy and El Sherbini, 1983).

\section{Results:-}

This study included 2636 pediatric patients out of the total 15840 patients who were admitted due to injury in Zagazig University Hospitals during the period from April 2013 to April 2015. 
Types of child injuries table (1)

Table 1:-Distribution of pediatric injuries among different Zagazig University Hospital's departments (N=2636).

\begin{tabular}{|l|c|c|}
\hline \multirow{2}{*}{ Department } & \multicolumn{2}{|c|}{$\begin{array}{c}\text { Total number of injured children admitted to ZUH } \\
\text { (N=2636) }\end{array}$} \\
\cline { 2 - 3 } & No. & \% \\
\hline Orthopedic & 998 & $37.8 \%$ \\
\hline Neurosurgery & 647 & $24.5 \%$ \\
\hline General surgery & 469 & $17.7 \%$ \\
\hline Toxicology & 290 & $11 \%$ \\
\hline Ophthalmic surgery & 189 & $7.1 \%$ \\
\hline Cardiothoracic surgery & 27 & $1 \%$ \\
\hline Pediatrics & 9 & $0.34 \%$ \\
\hline Ear, nose and throat & 7 & $0.26 \%$ \\
\hline
\end{tabular}

This study focused on children admitted in general surgery emergency ward and the results were presented in the light of (agent-host-environment) model (Haddon, 1980):

Agent:-

1. The most common form of energy in this study was mechanical energy and number of patients was (437 patients) table (2).

2. As regard the vector of trauma, road traffic accident was the most common cause. It was encountered in (221 patients), followed by falls in (106 patients). Pedestrian injury was the most common road traffic accident $(69 \%)$. Other vectors mentioned in (table3,4).

Table 2:-Association between causative energy and mortality among the injured children $(\mathrm{N}=469)$

\begin{tabular}{|c|c|c|c|c|c|c|c|}
\hline \multirow[t]{2}{*}{ Causative energy } & \multirow[t]{2}{*}{$\mathbf{N}$} & \multicolumn{2}{|c|}{$\begin{array}{c}\text { Alive } \\
(\mathrm{N}=448)\end{array}$} & \multicolumn{2}{|c|}{$\begin{array}{c}\text { Died } \\
(\mathbf{N}=21)\end{array}$} & \multirow[t]{2}{*}{\begin{tabular}{|c|} 
Chi-square \\
Test
\end{tabular}} & \multirow[t]{2}{*}{ p-value } \\
\hline & & No. & $\%$ & No. & $\%$ & & \\
\hline Mechanical & 437 & 418 & $95.7 \%$ & 19 & $4.3 \%$ & \multirow[t]{4}{*}{1.404} & \multirow[t]{4}{*}{0.705} \\
\hline Electrical & 11 & 10 & $90.9 \%$ & 1 & $9.1 \%$ & & \\
\hline Thermal & 12 & 11 & $91.7 \%$ & 1 & $8.3 \%$ & & \\
\hline Chemical & 9 & 9 & $100 \%$ & 0 & $0 \%$ & & \\
\hline
\end{tabular}

Table 3:-Association between the vector and mortality among the injured children $(\mathrm{N}=469)$

\begin{tabular}{|c|c|c|c|c|c|c|c|}
\hline \multirow[t]{2}{*}{ Vector } & \multirow[t]{2}{*}{$\mathbf{N}$} & \multicolumn{2}{|c|}{$\begin{array}{c}\text { Alive } \\
(\mathrm{N}=\mathbf{4 4 8})\end{array}$} & \multicolumn{2}{|c|}{$\begin{array}{c}\text { Died } \\
(\mathbf{N}=21)\end{array}$} & \multirow[t]{2}{*}{$\begin{array}{c}\text { Chi-square } \\
\text { Test }\end{array}$} & \multirow[t]{2}{*}{ p-value } \\
\hline & & No. & $\%$ & No. & $\%$ & & \\
\hline RTA & 221 & 206 & $93.2 \%$ & 15 & $6.8 \%$ & \multirow[t]{10}{*}{9.422} & \multirow[t]{10}{*}{0.399} \\
\hline Fall & 106 & 102 & $96.2 \%$ & 4 & $3.8 \%$ & & \\
\hline Sharp object & 72 & 72 & $100 \%$ & 0 & $0 \%$ & & \\
\hline Animal kick, fist blow & 20 & 20 & $100 \%$ & 0 & $0 \%$ & & \\
\hline Burn & 12 & 11 & $91.7 \%$ & 1 & $8.3 \%$ & & \\
\hline Foreign body & 12 & 12 & $100 \%$ & 0 & $0 \%$ & & \\
\hline Electricity & 11 & 10 & $90.9 \%$ & 1 & $9.1 \%$ & & \\
\hline Caustics & 9 & 9 & $100 \%$ & 0 & $0 \%$ & & \\
\hline Abuse & 4 & 4 & $100 \%$ & 0 & $0 \%$ & & \\
\hline Gun shot & 2 & 2 & $100 \%$ & 0 & $0 \%$ & & \\
\hline
\end{tabular}

Table 4:-Association between the vector and disability among the survived children ( $\mathrm{N}=448)$

\begin{tabular}{|c|c|c|c|c|c|c|c|}
\hline \multirow[t]{2}{*}{ Vector } & \multirow[t]{2}{*}{$\mathbf{N}$} & \multicolumn{2}{|c|}{$\begin{array}{l}\text { No disability } \\
(\mathbf{N}=353)\end{array}$} & \multicolumn{2}{|c|}{$\begin{array}{c}\text { Disability } \\
(\mathbf{N}=95)\end{array}$} & \multirow{2}{*}{$\begin{array}{c}\text { Chi- } \\
\text { square } \\
\text { Test }\end{array}$} & \multirow[t]{2}{*}{ p-value } \\
\hline & & No. & $\%$ & No & $\%$ & & \\
\hline RTA & 206 & 164 & $79.6 \%$ & 42 & $20.4 \%$ & 26.419 & 0.002 \\
\hline Fall & 102 & 65 & $63.7 \%$ & 37 & $36.3 \%$ & & \\
\hline Sharp object & 72 & 60 & $83.3 \%$ & 12 & $16.7 \%$ & & \\
\hline
\end{tabular}




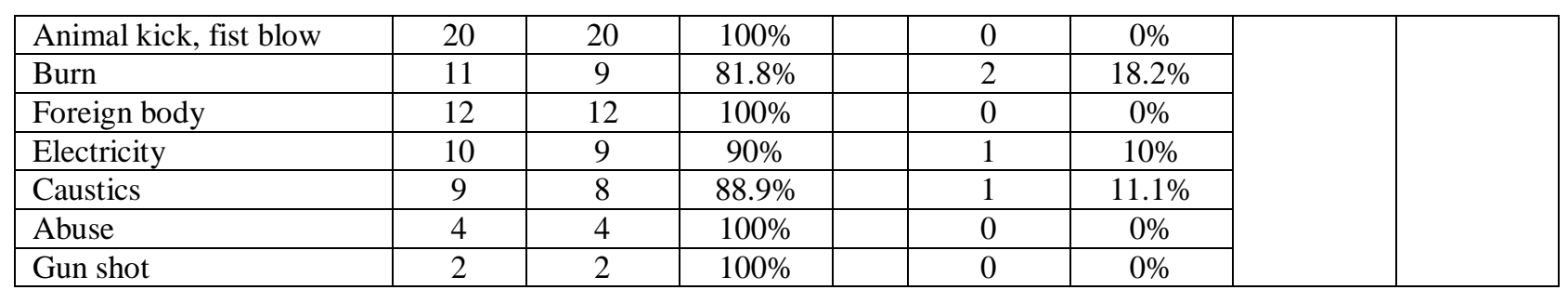

Host:-

1. Gender: 318 boys (67.8\%) were injured versus (151) girls (32.2\%), with a male-to-female ratio of approximately $(2.1: 1)$ table $(5,6)$.

2. Age: the most common age of trauma in this study was above $10-14$ years $(36.9 \%)$.

3. Developmental level: injuries were most common among young school children. When mechanisms of trauma were related to age groups in this study, we found that road traffic accidents were significantly more common among children aged from 10 to 14 years, whereas falls were significantly more common among children aged from 1 to 5years (table7,8).

4. According to injured areas of trauma in the body, the abdomen was the most common area (168 patients), head and neck (48 patients), chest (9 patients), pelvis (13 patients), multiple organs (43 patients), upper limb (143 patients) and lower limb (45 patients) (table8).

Table 5:-Association between gender and mortality among the injured children in pediatric surgery department $(\mathrm{N}=469)$.

\begin{tabular}{|c|c|c|c|c|c|c|c|}
\hline \multirow[t]{2}{*}{ Gender } & \multirow[t]{2}{*}{$\mathrm{N}$} & \multicolumn{2}{|c|}{$\begin{array}{c}\text { Alive } \\
(\mathrm{N}=\mathbf{4 4 8})\end{array}$} & \multicolumn{2}{|c|}{$\begin{array}{c}\text { Died } \\
(\mathrm{N}=21)\end{array}$} & \multirow[t]{2}{*}{$\begin{array}{c}\text { Chi-square } \\
\text { Test }\end{array}$} & \multirow[t]{2}{*}{ p-value } \\
\hline & & No. & $\%$ & No. & $\%$ & & \\
\hline Boys & 318 & 303 & $95.3 \%$ & 15 & $4.7 \%$ & \multirow[t]{2}{*}{0.132} & \multirow[t]{2}{*}{0.716} \\
\hline Girls & 151 & 145 & $96 \%$ & 6 & $4 \%$ & & \\
\hline
\end{tabular}

Table 6:-Association between sex and disability among the survived children following injury $(\mathrm{N}=448)$

\begin{tabular}{|c|c|c|c|c|c|c|c|}
\hline \multirow[t]{2}{*}{ Gender } & \multirow[t]{2}{*}{$\mathbf{N}$} & \multicolumn{2}{|c|}{$\begin{array}{c}\text { No disability } \\
(\mathrm{N}=353)\end{array}$} & \multicolumn{2}{|c|}{$\begin{array}{c}\text { Disability } \\
(\mathrm{N}=95)\end{array}$} & \multirow{2}{*}{$\begin{array}{c}\text { Chi- } \\
\text { square } \\
\text { Test }\end{array}$} & \multirow[t]{2}{*}{ p-value } \\
\hline & & No. & $\%$ & No. & $\%$ & & \\
\hline Boys & 303 & 236 & $77.9 \%$ & 67 & $22.1 \%$ & \multirow[t]{2}{*}{0.461} & \multirow[t]{2}{*}{0.497} \\
\hline Girls & 145 & 117 & $80.7 \%$ & 28 & $19.3 \%$ & & \\
\hline
\end{tabular}

Table 7:-Distribution of trauma vectors among age groups of the injured children in pediatric surgery department $(\mathrm{N}=469)$.

\begin{tabular}{|c|c|c|c|c|c|c|c|c|c|}
\hline \multirow[t]{3}{*}{ Vector } & \multirow[t]{3}{*}{$\mathbf{N}$} & \multicolumn{8}{|c|}{ Age group } \\
\hline & & \multicolumn{2}{|c|}{$\begin{array}{c}<1 \text { Year } \\
(N=15)\end{array}$} & \multicolumn{2}{|c|}{$\begin{array}{c}\text { 1-5 Years } \\
(\mathrm{N}=130)\end{array}$} & \multicolumn{2}{|c|}{$\begin{array}{c}\text { 5-10 Years } \\
(\mathrm{N}=151)\end{array}$} & \multicolumn{2}{|c|}{$\begin{array}{c}\text { 10-14 Years } \\
(\mathrm{N}=173)\end{array}$} \\
\hline & & No. & $\%$ & No. & $\%$ & No. & $\%$ & No. & $\%$ \\
\hline RTA & 221 & 3 & $20 \%$ & 38 & $29.2 \%$ & 65 & $43 \%$ & 115 & $66.5 \%$ \\
\hline Fall & 106 & 4 & $26.7 \%$ & 47 & $36.2 \%$ & 27 & $17.9 \%$ & 28 & $16.2 \%$ \\
\hline Sharp object & 72 & 6 & $40 \%$ & 18 & $13.8 \%$ & 28 & $18.5 \%$ & 20 & $11.6 \%$ \\
\hline Animal kick, fist blow & 20 & 0 & $0 \%$ & 3 & $2.3 \%$ & 7 & $4.6 \%$ & 10 & $5.8 \%$ \\
\hline Foreign body & 12 & 0 & $0 \%$ & 7 & $5.4 \%$ & 5 & $3.3 \%$ & 0 & $0 \%$ \\
\hline Electricity & 11 & 0 & $0 \%$ & 6 & $4.6 \%$ & 5 & $3.3 \%$ & 0 & $0 \%$ \\
\hline Caustics & 9 & 0 & $0 \%$ & 6 & $4.6 \%$ & 3 & $2 \%$ & 0 & $0 \%$ \\
\hline Wet burn & 7 & 2 & $13.3 \%$ & 4 & $3.1 \%$ & 1 & $0.7 \%$ & 0 & $0 \%$ \\
\hline Dry burn & 5 & 0 & $0 \%$ & 1 & $0.8 \%$ & 4 & $2.6 \%$ & 0 & $0 \%$ \\
\hline Abuse & 4 & 0 & $0 \%$ & 0 & $0 \%$ & 4 & $2.6 \%$ & 0 & $0 \%$ \\
\hline Gun shot & 2 & 0 & $0 \%$ & 0 & $0 \%$ & 2 & $1.3 \%$ & 0 & $0 \%$ \\
\hline
\end{tabular}


Table 8:-Association between the age group and disability among the survived children following injury in pediatric surgery department $(\mathrm{N}=448)$.

\begin{tabular}{|c|c|c|c|c|c|c|c|}
\hline \multirow[t]{2}{*}{ Age group } & \multirow[t]{2}{*}{$\mathbf{N}$} & \multicolumn{2}{|c|}{$\begin{array}{c}\text { No disability } \\
(\mathbf{N}=353)\end{array}$} & \multicolumn{2}{|c|}{$\begin{array}{c}\text { Disability } \\
(\mathrm{N}=95)\end{array}$} & \multirow[t]{2}{*}{$\begin{array}{c}\text { Chi-square T } \\
\text { est }\end{array}$} & \multirow[t]{2}{*}{ p-value } \\
\hline & & No. & $\%$ & No. & $\%$ & & \\
\hline$<1$ Year & 14 & 13 & $92.9 \%$ & 1 & $7.1 \%$ & \multirow[t]{4}{*}{5.015} & \multirow[t]{4}{*}{0.028} \\
\hline 1-5 Years & 123 & 104 & $83.2 \%$ & 21 & $16.8 \%$ & & \\
\hline 5-10 Years & 146 & 114 & $78.6 \%$ & 31 & $21.4 \%$ & & \\
\hline 10-14 Years & 165 & 122 & $74.4 \%$ & 42 & $25.6 \%$ & & \\
\hline
\end{tabular}

Table 9:-Site of injury among the injured children

\begin{tabular}{|l|c|c|}
\hline \multirow{2}{*}{ Site of injury } & \multicolumn{2}{|c|}{$\begin{array}{c}\text { The studied patients } \\
\text { (N=469) }\end{array}$} \\
\cline { 2 - 3 } & No. & $\%$ \\
\hline Abdomen & 168 & $35.8 \%$ \\
\hline Upper limb & 143 & $30.5 \%$ \\
\hline Head \& Neck & 48 & $10.2 \%$ \\
\hline Lower limb & 45 & $9.6 \%$ \\
\hline Multiple- organ & 43 & $9.2 \%$ \\
\hline Pelvis & 13 & $2.8 \%$ \\
\hline Chest & 9 & $1.9 \%$ \\
\hline
\end{tabular}

\section{Environment:-}

Physical environment:-

1. The most common physical environment was the streets where road traffic accidents occurred.

2. The vehicles in RTS were cars in (118 patients), motorcycles in (59 patients), bicycles in (27 patients), carts in (8 patients) and trains in (9 patients).

3. According to seasonal variation of injures, the summer was the highest prevalence $(50.6 \%)$ and no statistically significant relationship with mortality $(\mathrm{P}$ value $=0.627)$ but statistically significant relationship with disability $(\mathrm{P}$ value $=0.002)($ table10, 11).

\section{Psychosocial environment:-}

According to this study, pediatric trauma is more common among children living in low socioeconomic states (61\%) but there was no statistically significant relationship with mortality $(\mathrm{P}$ value=0.804) (table 12).

Table 10:-Association between the season of injury and mortality among the injured children $(\mathrm{N}=469)$

\begin{tabular}{|c|c|c|c|c|c|c|c|}
\hline \multirow[t]{2}{*}{$\begin{array}{l}\text { Season of } \\
\text { injury }\end{array}$} & \multirow[t]{2}{*}{$\mathbf{N}$} & \multicolumn{2}{|c|}{$\begin{array}{l}\text { Alive } \\
(\mathrm{N}=448)\end{array}$} & \multicolumn{2}{|c|}{$\begin{array}{l}\text { Died } \\
(\mathrm{N}=21)\end{array}$} & \multirow{2}{*}{$\begin{array}{l}\text { Chi- } \\
\text { square } \\
\text { Test }\end{array}$} & \multirow[t]{2}{*}{ p-value } \\
\hline & & No. & $\%$ & No. & $\%$ & & \\
\hline Summer & 237 & 224 & $94.5 \%$ & 13 & $5.5 \%$ & \multirow{4}{*}{1.743} & \multirow[t]{4}{*}{0.627} \\
\hline Spring & 112 & 107 & $95.5 \%$ & 5 & $4.5 \%$ & & \\
\hline Autumn & 67 & 65 & $97 \%$ & 2 & $3 \%$ & & \\
\hline Winter & 53 & 52 & $98.1 \%$ & 1 & $1.9 \%$ & & \\
\hline
\end{tabular}

Table 11:-Association between season of injury and disability among the survived children ( $\mathrm{N}=448)$

\begin{tabular}{|c|c|c|c|c|c|c|c|}
\hline \multirow[t]{2}{*}{$\begin{array}{l}\text { Season of } \\
\text { injury }\end{array}$} & \multirow[t]{2}{*}{$\mathbf{N}$} & \multicolumn{2}{|c|}{$\begin{array}{l}\text { No disability } \\
(\mathrm{N}=353)\end{array}$} & \multicolumn{2}{|c|}{$\begin{array}{l}\text { Disability } \\
\text { (N=95) }\end{array}$} & \multirow{2}{*}{$\begin{array}{l}\text { Chi- } \\
\text { square } \\
\text { Test }\end{array}$} & \multirow[t]{2}{*}{ p-value } \\
\hline & & No. & $\%$ & No. & $\%$ & & \\
\hline Summer & 224 & 167 & $74.6 \%$ & 57 & $25.4 \%$ & \multirow[t]{4}{*}{15.250} & \multirow[t]{4}{*}{0.002} \\
\hline Spring & 107 & 79 & $73.8 \%$ & 28 & $26.2 \%$ & & \\
\hline Autumn & 65 & 59 & $90.8 \%$ & 6 & $9.2 \%$ & & \\
\hline Winter & 52 & 48 & $92.3 \%$ & 4 & $7.7 \%$ & & \\
\hline
\end{tabular}


Table 12:-Association between the social level and mortality among the injured children $(\mathrm{N}=469)$

\begin{tabular}{|c|c|c|c|c|c|c|c|}
\hline \multirow[t]{2}{*}{ Social level } & \multirow[t]{2}{*}{$\mathbf{N}$} & \multicolumn{2}{|c|}{$\begin{array}{l}\text { Alive } \\
(\mathrm{N}=\mathbf{4 4 8})\end{array}$} & \multicolumn{2}{|c|}{$\begin{array}{l}\text { Died } \\
(\mathrm{N}=\mathbf{2 1})\end{array}$} & \multirow{2}{*}{$\begin{array}{l}\text { Chi- } \\
\text { square } \\
\text { Test }\end{array}$} & \multirow[t]{2}{*}{ p-value } \\
\hline & & No. & $\%$ & No. & $\%$ & & \\
\hline Low & 286 & 272 & $95.1 \%$ & 14 & $4.9 \%$ & \multirow[t]{3}{*}{0.436} & \multirow[t]{3}{*}{0.804} \\
\hline Intermediate & 142 & 137 & $96.5 \%$ & 5 & $3.5 \%$ & & \\
\hline High & 41 & 39 & $95.1 \%$ & 2 & $4.9 \%$ & & \\
\hline
\end{tabular}

Management:-

Table 13:-Type of management of the injured children $(\mathrm{N}=469)$

\begin{tabular}{|l|l|l|}
\hline \multirow{2}{*}{ Type of management } & \multicolumn{2}{|l|}{$\begin{array}{l}\text { The studied patients } \\
(\mathbf{N}=469)\end{array}$} \\
\cline { 2 - 3 } & No. & $\mathbf{2 4 . 7 \%}$ \\
\hline Conservative & 116 & $\mathbf{7 5 . 3 \%}$ \\
\hline Operative & 353 & \\
\hline
\end{tabular}

Disability:-

Table 14:-Disability among the survived children following injury ( $\mathrm{N}=469)$.

\begin{tabular}{|l|l|l|}
\hline \multirow{2}{*}{ Disability } & \multicolumn{2}{|l|}{$\begin{array}{l}\text { The studied patients } \\
(\mathbf{N = 4 4 8})\end{array}$} \\
\cline { 2 - 3 } & No. & $\%$ \\
\hline No & 353 & $\mathbf{7 8 . 8 \%}$ \\
\hline Temporarily & 59 & $\mathbf{1 3 . 2 \%}$ \\
\hline Permanent & 36 & $\mathbf{8 \%}$ \\
\hline
\end{tabular}

\section{Mortality:-}

1. Out of 469 children admitted to emergency ward of general surgery department; 21 patients died with mortality rate of $(4.47 \%)$.

2. Children of $10-14$ years had the highest mortality (38\%), followed by $1-5$ years old children $(23.8 \%)$.

3. This study revealed RTA as the major cause of injury, causing the highest mortality (71.4\%).

4. Eight died patients received pre-hospital care while 13 did not receive it. Seven deaths were attended by ambulance while fourteen deaths came without. There was no safety facility in 17 deaths.

5. One hundred and eight patients were managed during golden hour, five patients died out of them and one hundred and twenty three patients were managed after the golden hour, sixteen patients died out of them table(15'16'17'18).

Table 15:-Association between pre-hospital care and mortality among the injured children $(\mathrm{N}=469)$

\begin{tabular}{|c|c|c|c|c|c|c|c|}
\hline \multirow[t]{2}{*}{$\begin{array}{l}\text { Pre-hospital } \\
\text { care }\end{array}$} & \multirow[t]{2}{*}{$\mathbf{N}$} & \multicolumn{2}{|c|}{$\begin{array}{l}\text { Alive } \\
(\mathrm{N}=448)\end{array}$} & \multicolumn{2}{|c|}{$\begin{array}{l}\text { Died } \\
(\mathrm{N}=21)\end{array}$} & \multirow{2}{*}{$\begin{array}{l}\text { Chi- } \\
\text { square } \\
\text { Test }\end{array}$} & \multirow[t]{2}{*}{ p-value } \\
\hline & & No. & $\%$ & No. & $\%$ & & \\
\hline Not provided & 174 & 161 & $92.5 \%$ & 13 & $7.5 \%$ & \multirow[t]{2}{*}{5.796} & \multirow[t]{2}{*}{0.016} \\
\hline Provided & 295 & 287 & $97.3 \%$ & 8 & $2.7 \%$ & & \\
\hline
\end{tabular}

Table 16:-Association between near ambulance and mortality among the injured children in pediatric surgery department ( $\mathrm{N}=469)$.

\begin{tabular}{|c|c|c|c|c|c|c|c|}
\hline \multirow[t]{2}{*}{$\begin{array}{l}\text { Near } \\
\text { ambulance }\end{array}$} & \multirow[t]{2}{*}{$\mathbf{N}$} & \multicolumn{2}{|c|}{$\begin{array}{l}\text { Alive } \\
(\mathrm{N}=448)\end{array}$} & \multicolumn{2}{|c|}{$\begin{array}{l}\text { Died } \\
(\mathrm{N}=\mathbf{2 1})\end{array}$} & \multirow[t]{2}{*}{ Test $^{*}$} & \multirow[t]{2}{*}{ p-value } \\
\hline & & No. & $\%$ & No. & $\%$ & & \\
\hline Absent & 188 & 174 & $92.6 \%$ & 14 & $7.4 \%$ & \multirow[t]{2}{*}{11.073} & \multirow[t]{2}{*}{0.001} \\
\hline Present & 281 & 277 & $98.6 \%$ & 4 & $1.4 \%$ & & \\
\hline
\end{tabular}


Table 17:-Association between safety facility and mortality among the injured children ( $\mathrm{N}=469)$

\begin{tabular}{|c|c|c|c|c|c|c|c|}
\hline \multirow[t]{2}{*}{$\begin{array}{l}\text { Safety } \\
\text { facility }\end{array}$} & \multirow[t]{2}{*}{$\mathbf{N}$} & \multicolumn{2}{|c|}{$\begin{array}{l}\text { Alive } \\
(\mathrm{N}=448)\end{array}$} & \multicolumn{2}{|c|}{$\begin{array}{l}\text { Died } \\
(\mathrm{N}=21)\end{array}$} & \multirow{2}{*}{$\begin{array}{l}\text { Chi- } \\
\text { square } \\
\text { Test }\end{array}$} & \multirow[t]{2}{*}{ p-value } \\
\hline & & No. & $\%$ & No. & $\%$ & & \\
\hline Absent & 175 & 158 & $90.3 \%$ & 17 & $9.7 \%$ & \multirow[t]{2}{*}{17.899} & \multirow[t]{2}{*}{$<0.001$} \\
\hline Present & 294 & 290 & $98.6 \%$ & 4 & $1.4 \%$ & & \\
\hline
\end{tabular}

Table 18:-Association between management during golden hour and mortality among the injured children ( $\mathrm{N}=469)$

\begin{tabular}{|c|c|c|c|c|c|c|c|}
\hline \multirow[t]{2}{*}{$\begin{array}{l}\text { Golden hour } \\
\text { management }\end{array}$} & \multirow[t]{2}{*}{$\mathbf{N}$} & \multicolumn{2}{|c|}{$\begin{array}{l}\text { Alive } \\
(\mathrm{N}=\mathbf{4 4 8})\end{array}$} & \multicolumn{2}{|c|}{$\begin{array}{l}\text { Died } \\
(\mathrm{N}=21)\end{array}$} & \multirow{2}{*}{$\begin{array}{l}\text { Chi- } \\
\text { square } \\
\text { Test } \\
\end{array}$} & \multirow[t]{2}{*}{ p-value } \\
\hline & & No. & $\%$ & No. & $\%$ & & \\
\hline No management & 139 & 120 & $86.3 \%$ & 19 & $13.7 \%$ & \multirow[t]{2}{*}{35.618} & \multirow[t]{2}{*}{$<0.001$} \\
\hline $\begin{array}{l}\text { Effective } \\
\text { management }\end{array}$ & 330 & 327 & $99.1 \%$ & 3 & $0.9 \%$ & & \\
\hline
\end{tabular}

\section{Discussion:-}

In this study the prevalence of pediatric injuries was $(16.64 \%)$ of all injuries received by Zagazig University Hospitals. Another study done at Naraingarh, India reported a prevalence of 5.5\% (Singhi et al., 2004). This was probably due to delayed presentation to tertiary institute (either via referrals or direct admission), or probably due to the lack of knowledge and low literacy levels among the parents of these children (Sharma et al, 2011).

Waly et al mentioned in their study, and in reference to agent-host-environment model; that the most critical host factor that carries the risk for BAT (blunt abdominal trauma) was boys aged 5 to 9 years (Waly et al, 2011). In the study conducted by Sharma et al; the mean age of presentation was 6.3 years and boys were more commonly hospitalized than girls. Sharma et al attributed that to the more freedom given to the boys as well as free hand to work or play outside their homes. Boys to girls ratio was (1.9:1); School age children (6-12 years) were the most commonly affected agent group in Sharma et al study ( Sharma et al, 2011). Similarly; in the present study the researchers found that the mean age of presentation was 6.5 years and boys were injured more than girls with a male-to-female ratio of approximately (2.1: 1). This comparability of results can be explained by the similar social habits of giving boys more space of freedom.

In this study orthopedic injuries were the highest prevalence followed by head and abdominal injuries. These findings are matched with those of Sharma et al (2011). They described that children mostly suffered from orthopedic injuries while among the non-orthopedic injuries; head and abdominal injuries were the most commonly seen in the children (Sharma et al, 2011).

The most common form of energy causing injuries in this study was mechanical energy (93.1\%) by RTS (47.1\%) followed by home accidents $(29.8 \%)$. Also Waly et al found that mechanical energy that was most commonly transmitted through RTAs (55.8\%), (Waly et al, 2011).

In the present study the physical abuse and gun shots were small numbers (4 patients) and ( 2 patients). Holland et al study also revealed that Sexual assault and gunshot wounds were a small percentage and this because of the attending psychological morbidity which most times extend into adult life (Holland et al., 2005).

According to Kraus et al and Peden et al preschool children are at greatest risk of falls, whereas young school age children are at greatest risk of pedestrian injuries, bicycle-related, and motor-vehicle occupant injuries (Kraus et al., 1998) and (Peden et al., 2008).

In our study the teenagers (10-14 years) were the most liable to RTA. Falls were more common in 1-5 years age group, followed by injury by sharp objects, animal kicks and fist. These findings correlate with what is reported by Constan et al., in 1995. They found that in pre-school age (1-5) years the prevalence of falls increased to be less than RTAs by few percentage and followed by sharp objects that was the commonest vector in children less than 1 year old, (Constan et al., 1995). In the present study, most of the victims of RTAs were pedestrians and this finding is similar to that derived from the study done at Maput and Tehran (Petersburgo et al, 2010). 
As regards the injured site, this study found that the abdomen was the most common site of injury $35.8 \%$ followed by the upper limb $30.4 \%$. The management by surgical intervention was about $75 \%$ of patients. In the study of Ewen et al; they found that abdominal injury in children is a major cause of severe injury and also is the most common cause of initially missed fatal injury in children. It is usually caused by blunt injury due to RTAs (Ewen et al, 2008).

This study proved that there was high significant association between the survival and the management during golden hour and the presence of (near ambulance, pre hospital care, and safety facilities). A 2005 study by Pons et al found that Emergency Medical Service (EMS) response time within 4 minutes resulted in a significant survival benefit for patients with intermediate and high risk of mortality (Pons et al, 2005). However, another 2012 German study by Kleber et al found no significant survival advantage for trauma patients with shorter pre-hospital rescue times (Kleber et al., 2013). Kleber et al finding is supported by studies conducted in Canada (Stiell, et al., 2008).

As regard of the site of trauma, the road was and the commonest $(57.1 \%)$ and this result was similar with the study conducted by Waly et al 201. On the other hand Sharma et al found that the home to be the most common place of injury (Sharma et al, 2011). According to socioeconomic environment child injuries results were more prevalent among children living in low socioeconomic states (62\%). Similarly, Waly et al, found that BAT is significantly more common among children living in low socioeconomic states (67\%), (Waly et al, 2011). In this 2 years study 21 patients died with mortality rate of (4.47\%). The highest mortality (38\%) was in the age group from (10-14) years, followed by 1-5 years age group (23.8\%). Mortality was higher in boys. RTA was most common cause of death and associated with the highest mortality (71.4\%), followed by fall from height (19\%) and burns (10\%). Sharma et al, found that most mortality in their study occurred in the 1-3 year age group (Sharma et al, 2011). Bener et al., also reported the same result in his study (Bener et al., 1998).

\section{Conclusion:-}

In this study children admitted at surgery department ward were (469 patients) out of 2636 children had different types of injuries and in the light of (agent-host-environment) model this study revealed that:-

Host:-

School age children were the most commonly injured with the mean age of presentation 6.5 years. Boys to girls' ratio were 2.1: 1and abdominal injuries were the commonest. Mortality rate was (4.47\%).

\section{Agent:-}

Mechanical energy was the most common energy. Road traffic accident was the commonest vector.

\section{Environment:-}

Roads were the most common site for child injury and more common among children living in low socioeconomic states.

There was significant association between pre-hospital care, the presence of near ambulance, safety facility and management during golden hour with survival and no significant association between the place of trauma and the social level with survival. 


\section{References:-}

1. Amira H. Waly, Ismail M. Tantawy and Khalid S. Shreef. Agent-host-environment model of blunt abdominal trauma in children: 5-year experience and preventive inferences in Zagazig University-Egypt. Annals of Pediatric Surgery 2011, 7:61-65.

2. Bener A, Al-Salman KM, Pugh RN. Injury mortality and morbidity among children in the United Arab Emirates. Eur J Epidemiol. 1998;14:175-8. [PubMed]

3. Blackwell TH, Kaufman JS. Response time effectiveness: comparison of response time and survival in an urban EMS system. Acad Emerg Med 2002; 9:288-295.

4. Christoffel, T. \& Gallagher, S. S. (2006). Injury Prevention and Public Health Practical Knowledge, Skills and Strategies. 2nd ED. Jones and Bartlett Publishers.

5. Clarke JR, Trooskin SZ, Doshi PJ, et al. Time to laparotomy for intra-abdominal bleeding from trauma does affect survival for delays up to 90 minutes. J Trauma 2002; 52:420-425.

6. Cooper A, Jerry D, George W, Holcomb III . et al., (2014). Ashcraf,s pediatric surgery. Chapter 14:early assessment and management of trauma, p:117.

7. Crandall M, Chiu B, Sheehan K (2006) Injury in the first year of life: risk factors and solutions for high-risk families. J Surg Res 133: 7-10.

8. Damashek A, Williams NA, Sher K, Peterson L (2009) Relation of caregiver alcohol use to unintentional childhood injury. J Pediatr Psychol 34: 344-353.

9. Dickinson E, Limmer D, O'Keefe MF, Grant HD, Murray R (2008). Emergency Care (11th Edition). Englewood Cliffs, New Jersey: Prentice Hall. pp. 848-52.

10. Dickinson E, Limmer D, O'Keefe MF, Grant HD, Murray R (2008). Emergency Care (11th Edition). Englewood Cliffs, New Jersey: Prentice Hall. pp. 848-52.

11. Ehrlich PF, Drongowski A, Swisher-McClure S, et al. (2008) the importance of a preclinical trial: a selected injury intervention program for pediatric trauma centers. J Trauma; 65:189-95.

12. Ehrlich PF, Maio RF, Drongowski RS, Wagaman M, Cunningham R,Walton M. (2009) Alcohol interventions for trauma patients are not just for adults: justification for brief interventions for the injured adolescent at a pediatric trauma center. J Trauma; [in press].

13. Fahmy SI, El Sherbini AF. Determining simple parameters for social classification for health research. Bull High Inst Public Health 1983; 235:1-14.

14. Fathy H. Injury statistics and control program in Egypt. Faculty of medicine, Suez Canal University, Egypt; 2005.

15. Frederick B and Rogers, MD, MS, FACS. The Journal of Lancaster General Hospital. Spring 2014.Vol. 9.

16. Grossman DC, Kim A, MacDonald SC, et al. Urban-rural differences in pre-hospital care of major trauma. J Trauma 1997; 42:723-729.

17. Guyer B., and Gallagher S.S. An approach to the epidemiology of childhood injuries. Pediatric Clin. N. Am., 32 (5): $5-15,1985$.

18. Haddon W. (1980) Advances in the epidemiology of injuries as a basis for public policy. Public Health Rep; 95:411-21.

19. Haynes R, Reading R, Gale $\mathbf{S}$ (2003) Household and neighborhood risks for injury to 5-14 year old children. Social Science and Medicine 57: 625-636.

20. Holland A (2005) J:Paediatric Trauma:J Pediatr Child Health:;41(12);623-4 (ISSN:1034-4810).

21. Kendrick D, Marsh P (2001). How useful are socio-demographic characteristics in identifying children at risk of unintentional injury? Public Health 115: 103-107.

22. Kendrick D, Mulvaney C, Burton P, Watson M (2005) Relationships between child, family and neighborhood characteristics and childhood injury: a cohort study. Soc Sci Med 61: 1905-1915.

23. Kleber C, Lefering R, Kleber A, et al. Rescue time and survival of severely injured patients in Germany. Unfallchirurg 2013; 116(4):345-350.

24. Kraus J, Peek Asa C, Vimalachandra D. Injury control: the public health approach. In: Wallace R, editor. Public health and preventive medicine. 14th ed. Stamford, CT: Appleton \& Lange; 1998. pp. 1209-1222.

25. L.J. Paulozzi and R. Patel, R, "Trends in motorcycle fatalities associated with alcohol-impaired drivingUnited States-1983, 2003," Morbidity and Mortality Weekly Report, 53(47), 1103-1106, 2004.

26. Lalloo R, Sheiham A (2003) Risk factors for childhood major and minor head and other injuries in a nationally representative sample. Injury 34: 261-266.

27. Laursen B, Nielsen JW (2008) Influence of socio-demographic factors on the risk of unintentional childhood home injuries. Eur J Public Health 18: 366-370. 
28. Laursen B, Nielsen JW (2008) Influence of sociodemographic factors on the risk of unintentional childhood home injuries. Eur J Public Health 18: 366-370.

29. Little, Wendalyn K. (1 March 2010). "Golden Hour or Golden Opportunity: Early Management of Pediatric Trauma". Clinical Pediatric Emergency Medicine 11 (1): 4-9. doi: 10.1016/j.cpem.2009.12.005.

30. Mukesh Sharma, B. K. Lahoti, Gaurav Khandelwal, R. K. Mathur, S. S. Sharma, and Ashok Laddha. J Indian Assoc Pediatr Surg. 2011 Jul-Sep;16(3):88-92.doi: 10.4103/0971-9261.83484 PMCID: PMC3160060.

31. O'Connor TG, Davies L, Dunn J, Golding J (2000) Distribution of accidents, injuries, and illnesses by family type. ALSPAC Study Team. Avon Longitudinal Study of Pregnancy and Childhood. Pediatrics 106: E68.

32. Peden M, Hyder AA. Conclusions and recommendations. In: Peden M, Oyegbite K, Ozanne Smith J, Hyder AA, Branche C, Rahman AF, et al. editors. World report on child injury prevention. World Health Organization (WHO); 2008. p.72.

33. Petersburgo DD, Keyes CE, Wright DW, Click LA, Macleod JBA, Sasser SM. The epidemiology of childhood injury in Maputo, Mozambique. Int J Emerg Med. 2010;3:157-63.

34. Pons PT, Haukoos JS, Bludworth W, et al. Paramedic response time: does it affect patient survival? Acad Emerg Med 2005;12:594-600.

35. Runyan CW. Using the Haddon Matrix: introducing the third dimension, (1998) Inj Prev; 4:302-7.

36. Schwebel DC, Brezausek CM (2008) chronic maternal depression and children's injury risk. J Pediatric Psychol 33: 1108-1116.

37. Schwebel DC, Brezausek CM (2008) Chronic maternal depression and children's injury risk. J Pediatr Psychol 33: 1108-1116.

38. Singhi S, Gupta G, Jain V. Comparison of childhood emergency patients in a tertiary care hospital vs a community hospital. Indian Pediatr. 2004; 41:67-72. [PubMed]

39. Stiell IG, Nesbitt LP, Pickett W, et al. The OPALS major trauma outcome study: impact of advanced lifesupport on survival and morbidity. CMAJ 2008;178:1141-1152

40. Thompson MJ, Rivara FP. Bicycle-related injuries. Am Fam Physician.2001; 63:2007-2014.

41. Tien HCN, Jung V, Pinto R, et al. Reducing time to treatment decreases mortality of trauma patients with acute subdural hematoma.Ann-Surg2011;253:1178-1183.

42. Winqvist S, Jokelainen J, Luukinen H, Hillbom M (2007) Parental alcohol misuse is a powerful predictor for the risk of traumatic brain injury in childhood. Brain Inj 21: 1079-1085. 